\title{
Description and performance
}

\section{'Hamdan' and 'Qasim' Desert-adapted Winter Squashes}

\author{
Aly M. Ibrahim ${ }^{1}$, A.I. Al-Suliman ${ }^{2}$, and K.A. Al-Zeir ${ }^{2}$ \\ National Agriculture and Water Research Center, P.O. Box 17285, Riyadh \\ 11484, Kingdom of Saudi Arabia
}

\section{Additional index words. pumpkin, Cucurbita moschata, squash}

The National Agriculture and Water Research Center in conjunction with the U.S. Dept. of Agriculture, under the Agriculture and Water Project of the United States-Saudi Arabian Joint Commission, started a program to develop, improve, and introduce vegetable crops and varieties that are suitable to the Saudi environment and local consumers' tastes.

In the Kingdom of Saudi Arabia only one variety of winter squash, Cucurbita moschata (Duch. ex lam) Duch. ex Poir, is marketed. It is known as local or "Egyptian" pumpkin. The Arabic names for it are "Karra Assaly" or "Karra Misry." Egyptian pumpkin was originally introduced to the Kingdom by Egyptian expatriates. In Egypt it is called "Istanbuli" pumpkin, after the city in Turkey from which it was probably introduced. The local variety is characterized by heat tolerance, insect resistance, excellent keeping quality of the fruit, and great diversity in fruit traits, including shape, size, color, and flesh thickness. Its fruit are large and have a thin rind and large seed cavity. Because of its size, large portions of a fruit may be wasted or spoiled if the consumer cannot use the fruit quickly. The Egyptian pumpkin is common in Saudi Arabia. It is very popular and is especially important in the Qasim area.

To our knowledge, there is no previous information available on any effort conducted for improvement of Egyptian pumpkin for desirable characteristics, such as a longer neck and a smaller seed cavity of the fruit, which bring a high price and are cherished by consumers. 'Hamdan' and 'Qasim' were selected from the local pumpkin.

\section{Origin}

The local pumpkin segregates for fruit size and shape (Fig. 1). The shape may be round, oblong, oval, or oblate and with or without a

Received for publication 15 Aug. 1995. Accepted for publication 2 Mar. 1996. The cost of publishing this paper was defrayed in part by the payment of page charges. Under postal regulations, this paper therefore must be hereby marked advertisement solely to indicate this fact.

${ }^{1}$ Vegetable Horticulturist, U.S. Dept. of Agriculture, Foreign Agricultural Service. Current address: 1318 Dickens Dr., Salinas, CA 93901.

${ }^{2}$ Research Assistant. long neck. Separate selection programs were initiated to develop two distinct varieties. In one program, a plant with small fruit was selected after four generations of selection and inbreeding from an open-pollinated population of the Egyptian pumpkin. From this plant, 100 seeds were planted. Each plant was selfed. Ten round small fruit, with small seed cavities, were selected and bulked for two more generations. This procedure was followed by three more generations of open pollination, mass selection, and testing. The resulting population was named 'Hamdan'.

In the second program, a long-necked fruit was selected from a large population of Egyptian pumpkins at a local market in the Qasim area in 1989. Seeds of that fruit were planted at the National Agriculture and Water Research Center in Riyadh. Each plant was selfed. A single fruit selection scheme was adopted to achieve a long, straight, cavityfree neck and small bulb, and dark orange flesh with few fibers (Unander and VarelaRamirez, 1982). Seeds from several selected fruit were then bulked until $\mathrm{F}_{5}$. Subsequently, open pollination by honeybees was allowed from $\mathrm{F}_{5}$ to $\mathrm{F}_{9}$. The resulting selection was named 'Qasim'.
'Hamdan' has small fruit of uniform shape. The skin of the fruit is cream-colored (Fig.1), and the flesh color is light orange. The fruit diameter and cavity are smaller than those of the local variety. The flesh of 'Hamdan' is thicker than that of the local variety (Table 1).

Fruit of 'Hamdan' are easy to peel, have smooth texture, and, in informal taste tests, seemed sweeter than the local variety. Cooking time is similar. Fruit mature in 122 days from planting to harvest. The vines are vigorous; the plant extends to $5 \mathrm{~m}$ in diameter.

'Hamdan' averages three fruit per plant; the local variety averages one. 'Hamdan' has yielded $\approx 11 \%$ more than the local variety.

'Qasim' fruit is 62 to $87 \mathrm{~cm}$ long. The neck portion of the fruit represents $70 \%$ of the total fruit length and is 40 to $60 \mathrm{~cm}$ long. The neck weight constitutes $66 \%$ of the total fruit weight. The neck has solid orange-colored flesh. The bulb is small with a small cavity; seeds are embedded in the bulb. The skin of the fruit is cream-colored with a touch of bronze at harvest (Fig. 2). Fruit mature in 112 days. Vines are vigorous, extending to $>3 \mathrm{~m}$. Leaves are dark green and mottled around the veins.

'Qasim' averagedtwofruitperplantandyielded $27 \%$ more than the local variety (Table 1).

As selections from the local pumpkin population, 'Hamdan' and 'Qasim' grow well in the hot, dry Saudi environment. 'Hamdan' and 'Qasim' may be planted in the spring in the Riyadh, Al-Kharj, and Qasim areas or in the fall in the Farsha and Wadi Al-Dawasir areas. Fruit of 'Hamdan' and 'Qasim' have excellent keeping and storing quality. They may be kept for 2 months at room temperature and $20 \%$ to $30 \%$ relative humidity. They are also suitable for export.

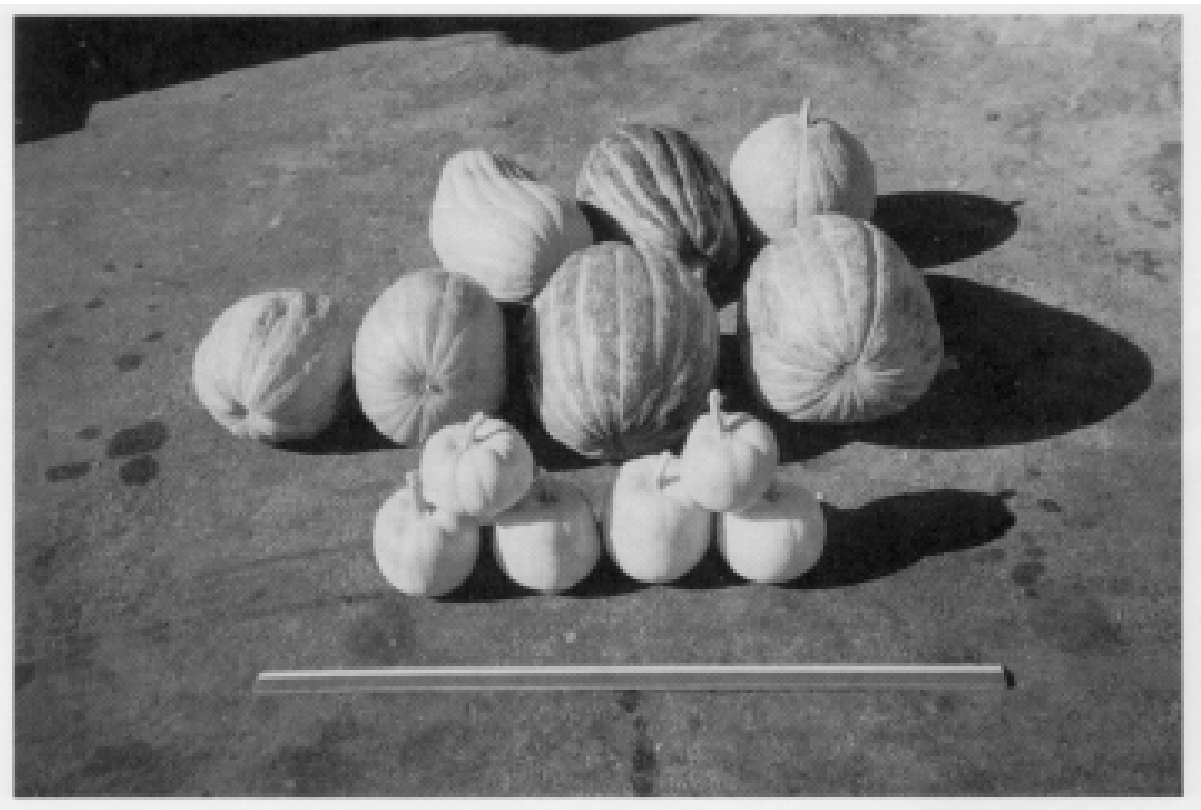

Fig. 1. (front) 'Hamdan' winter squash, (back) local pumpkin. Ruler is $60 \mathrm{~cm}$. 


\section{Cultivar \& Germplasm Releases}

Table 1. A comparison of selected traits among Saudi Arabia's local pumpkin, 'Hamdan', and 'Qasim'.

\begin{tabular}{|c|c|c|c|c|c|c|c|c|c|}
\hline \multirow[b]{2}{*}{ Pumpkin } & \multicolumn{2}{|c|}{$\begin{array}{c}\text { Wt } \\
(\mathrm{kg})\end{array}$} & \multicolumn{2}{|c|}{$\begin{array}{l}\text { Fruit } \\
\text { diam } \\
(\mathrm{cm})\end{array}$} & \multicolumn{2}{|c|}{$\begin{array}{c}\text { Flesh } \\
\text { thickness } \\
(\mathrm{cm})\end{array}$} & \multicolumn{2}{|c|}{$\begin{array}{l}\text { Cavity } \\
\text { diam } \\
(\mathrm{cm})\end{array}$} & \multirow{2}{*}{$\begin{array}{c}\text { Total }{ }^{y} \\
\text { yield } \\
\left(\mathrm{t}^{\circ} \mathrm{ha}^{-1}\right) \\
\end{array}$} \\
\hline & Range & Mean & Range & Mean & Range & Mean & Range & Mean & \\
\hline Local & $7.0-17.0$ & 11.0 & $23.0-31.0$ & 27.2 & $2.5-4.2$ & 3.2 & $17.0-27.0$ & 21.5 & 265 \\
\hline Hamdan & $1.1-4.2$ & 3.0 & $13.0-17.5$ & 15.2 & $2.5-4.0$ & 3.5 & $6.5-9.0$ & 8.3 & 295 \\
\hline Qasim & $5.0-9.0$ & 7.0 & $19.0-22.0$ & 20.0 & $18.0-19.0$ & 18.5 & $11.0-13.0$ & 12.0 & 336 \\
\hline
\end{tabular}

${ }^{2}$ Test was conducted in the Riyadh area. The data represent an average of 30 plants of each variety. The plot was $500 \mathrm{~m}^{2}$. The planting was $3.5 \mathrm{~m}$ between rows and $1 \mathrm{~m}$ within row.

${ }^{y}$ Nonsignificant by $t$ test at $P \leq 0.05$.

\section{Availability}

'Hamdan' and 'Qasim' seeds are available in small quantities for research from the $\mathrm{Na}$ tional Agriculture and Water Research Center, P.O. Box 17285, Riyadh 11484, Saudi Arabia.

\section{Literature Cited}

Unander, D.W. and F. Varela-Ramirez. 1982. Selection of pulp color and thickness in calabaza. HortScience 4:755-757.



Fig. 2. 'Qasim' winter squash. Ruler is $60 \mathrm{~cm}$. 